\title{
The uptake of silver(l) from chloride solutions by amine extractants
}

\author{
Katarzyna Wejman ${ }^{1, *}$, and Magdalena Pilśniak-Rabiega ${ }^{1}$ \\ ${ }^{1}$ Wroclaw University of Science and Technology, Faculty of Chemistry, Division of Analytical Chemistry and Chemical Metallurgy, \\ 50-370 Wrocław, Poland
}

\begin{abstract}
The amine extractants, bis(2-ethylhexyl)amine, N,N-dimethylethanolamine, and trioctylamine were used to recover silver(I) ions from chloride solutions. The effect of the $\mathrm{pH}$, contact time, extractant concentration and reextraction were studied. It was found that extraction of silver(I) depended on the $\mathrm{pH}$, extractant concentration and strongly on the contact time. Reextraction of $\mathrm{Ag}(\mathrm{I})$ ions from the loaded organic phase showed that the metal can be removed in over $50 \%$ for the three extractant using sodium hydroxide. The recovery of silver from the chloride leaching solutions were above $85 \%$ for bis(2-ethylhexyl)amine, above $58 \%$ for N,N-dimethylethanolamine, and above $70 \%$ for trioctylamine.
\end{abstract}

\section{Introduction}

Use Sulphurous copper ores have polymetallic character, which means that they contain a series of other chemical elements and some of them may be significant for reclamation process. In practice, there are none other recognised copper ore deposits in the world which contains so many supporting metals than polymetallic and polymineral copper ore deposits in Legnicko - Głogowski Copper Zone. The existence of supporting elements has a big influence on technological process; it could be the reason of serious disturbances as well as the source of additional profit. The supporting elements, which concentrate in different production streams, constitute useful ingredients, such as silver, nickel, cobalt, gold, platinum, or undesirable pollutants whitch have to be removed from processing systems $(\mathrm{Pb}, \mathrm{As}, \mathrm{Cd}, \mathrm{Hg}, \mathrm{F}, \mathrm{Sb})$ $[1,2]$.

According to various sources, the demand for silver is still increasing - it is mainly used in the production of kitchen vessels, photographic industry, production of electronic, electric and cooling devices, as well as manufacturing jewellery and coins. When there are exploited, the majority of those products may become the potential raw material for the silver reclamation. It is now being estimated that about a half of worldwide production of silver is a result of the reclamation of its various raw materials and wastes, which is a phenomenon of growing tendency [3-5].

The polish national leader of silver manufacture is Lower Silesia's KGHM Poland, which is now collecting silver using pyrometallurgical techniques. However, the diversity, dynamically changing characteristic and type of raw materials, which contain a great part of valuable metals resources, led to the growing interest in hydrometallurgical methods. Those methods are more flexible concerning scale and technical capabilities; moreover they guarantee at the same time a big changeability of the material and a high effectiveness of the processes. Taking silver raw materials into consideration, it is possible to treat them in an effective way using hydrometallurgical methods [2]. The basic process is leaching a solid chase that contains silver mostly in cyanide solutions, as well as chloride, thiosulfate, thiourea, ammonia, or by using concentrated sulphuric acid in increased temperature (ca. $200{ }^{\circ} \mathrm{C}$ ) $[6$, 7]. Even though in this case it is cyanide leaching that is most commonly used, chloride leaching is much more beneficial after all, because it is less toxic and the process itself is more efficient and less time - consuming, while technological costs remain significantly lower [6].

Selective and effective extraction of the metal from the solutions after leaching is mostly achieved with solvent extraction, or polymeric resin sorption [8, 9]. They may be used in hydrometallurgical methods of metals recovery, which allows to concentrate and extract metals from the solutions that contains only trace amounts of a particular metal (even to the concentration of a few $\mathrm{ppm}$ ), sometimes directly in the production plants where e. g. waste solutions are produced. In comparison with pyro-metallurgical methods, hydrometallurgical ones do not require high temperatures and do not produce harmful gases (carbon monoxide), particulates (lead and arsenic), while investment costs are significantly low. Moreover, solvent extraction process is highly selective and effective; it is also not time - consuming and the apparatus used is not complicated.

Solvent extraction, also called liquid-liquid extraction is one of the most important, economical and practical process in hydrometallurgical industry for separation and purification of several metals - nonferrous, rare earths, the platinum group metals (PGMs). This method have

\footnotetext{
* Corresponding author: katarzyna.wejman@pwr.edu.pl
} 
a number of advantages like: high selectivity and metal purity [10-12]. Despite widespread use in industrial hydrometallurgical processes, phosphorus-containing compounds are considered less environmentally friendly than extractants which have hetero atoms such as oxygen, nitrogen or sulphur in their structures [13]. For this reason, this study tested the extraction of $\mathrm{Ag}(\mathrm{I})$ chloride solutions with amines.

Extracting silver in solvent extraction processes was widely examined and described in scientific literature. However, the usage of solvent extrication for recovering silver from solutions after chloride leaching, where the feed was a remain from atmospheric leaching of the concentrate from ZWR Lublin, was previously described in a scientific work only with the usage of three amines [14]. In order to broaden the perspective of the process of recovering silver from chloride solutions containing over $4 \mathrm{M}$ chloride ions, the below examination was presented. The objective of this study was to examine the process of silver(I) ions extraction from chloride solutions. Effect of the initial $\mathrm{pH}$, contact time, extractant concentration and stripping on silver(I) recovery was investigated. Additionally, the process of silver(I) ions extraction was tested from chloride pregnant leach solutions (PLS), coming from an atmosphere leaching of the copper flotation concentrate from Lubin Concentrator (KGHM Polska Miedź S.A.).

\section{Experimental}

\subsection{Reagents}

Amine extractants were used as organic solvents without further purification, detailed information was included in Table 1. Ksylene (Avantor) were the diluent.

Table 1. Characteristics of the amine extractants.

\begin{tabular}{|c|c|c|c|}
\hline Amine & Sign & $\begin{array}{c}\text { Concentrati } \\
\text { on [\%] }\end{array}$ & Producer \\
\hline $\begin{array}{c}\text { N,N- } \\
\text { Dimethyletha } \\
\text { nolamine }\end{array}$ & DMEA & 99.5 & $\begin{array}{c}\text { Sigma- } \\
\text { Aldrich }\end{array}$ \\
\hline $\begin{array}{c}\text { Bis(2- } \\
\text { ethylhexyl)a } \\
\text { mine }\end{array}$ & BEHA & 99.0 & $\begin{array}{c}\text { Sigma- } \\
\text { Aldrich }\end{array}$ \\
\hline Trioctylamine & TOA & 98.0 & $\begin{array}{c}\text { Sigma- } \\
\text { Aldrich }\end{array}$ \\
\hline
\end{tabular}

\subsection{General extraction procedure}

Synthetic solutions of silver(I) ions were prepared by dissolving a known amount of silver nitrate (AgNO3) in distilled water with hydrochloric acid and sodium chloride $(3.7 \mathrm{~g} / \mathrm{L}$ of $\mathrm{HCl}$ and $234 \mathrm{~g} / \mathrm{L}$ of $\mathrm{NaCl})$. The initial $\mathrm{Ag}(\mathrm{I})$ ion concentration for synthetic solutions was 50 $\mathrm{mg} / \mathrm{L}$. Chloride leach solutions were generated in atmosphere chloride leaching of a solid residue after sulphate leaching of the commercial flotation sulphide concentrate produced at the Lubin Concentrator (KGHM Polska Miedź S.A.). Solutions after chloride leaching were contained silver(I) and other metals, such as $\mathrm{Cu}(\mathrm{II})$, $\mathrm{Pb}(\mathrm{II}), \mathrm{Fe}(\mathrm{III}), \mathrm{Zn}(\mathrm{II}), \mathrm{Co}(\mathrm{II}), \mathrm{Ni}(\mathrm{II})$. The chemical composition of "Lubin" solutions after chloride leaching was presented in Table 2. The organic phase was contained one of three extractants and ksylene as a diluent. Different solutions were used as stripping agent: $\mathrm{NaOH}, \mathrm{NaNO} 3, \mathrm{NH} 4 \mathrm{NO} 3$ and $\mathrm{NH} 3 \cdot \mathrm{H} 2 \mathrm{O}$. Aqueous and organic phases were shaken at $325 \mathrm{rpm}$ and ambient temperature $\left(23 \pm 1^{\circ} \mathrm{C}\right)$ using a mechanical shaker type ELPAN 357. The concentration of $\operatorname{Ag}(\mathrm{I})$ ion in the aqueous phase before and after the extraction and the reextraction was determined by means of flame atomic absorption spectrometry (FAAS) using a Varian SpectrAA 20 Plus instrument.diluent.

Table 2. Composition of solutions after chloride leaching.

\begin{tabular}{|c|c|c|c|c|c|c|c|}
\hline \multirow{2}{*}{ Part } & \multicolumn{7}{|c|}{ Metal concentration $[\mathrm{mg} / \mathrm{L}]$} \\
\hline & $\operatorname{Ag}(\mathbf{I})$ & $\mathrm{Pb}(\mathrm{II})$ & $\mathrm{Cu}(\mathrm{II})$ & $\mathrm{Zn}(\mathrm{II})$ & $\mathrm{Ni}(\mathrm{II})$ & $\operatorname{Co}($ II) & $\mathrm{Fe}(\mathrm{III})$ \\
\hline$a$ & 44.8 & 197.9 & 25.8 & 30.6 & 25.8 & 26.4 & - \\
\hline$b$ & 46.2 & 501.2 & 364.2 & 12.4 & 15.3 & 23.7 & 501.2 \\
\hline
\end{tabular}

\section{Results and discussions}

\subsection{The effect of the initial $\mathrm{pH}$}

It was expected that the efficiency of the extraction process of $\mathrm{Ag}$ by amine extractants, bis(2ethylhexyl)amine (BEHA), N,N-dimethylethanolamine (DMEA), and trioctylamine (TOA) should mainly depend on the metal-extractant complex formation and the concentration of the extractable $\mathrm{Ag}(\mathrm{I})$ species (closely related to $\mathrm{pH}$ of the aqueous phase). Additionally, it was presumed that in case of the amine extractant use in this experiment nitrogen could positively influence on extraction of $\operatorname{Ag}(\mathrm{I})$, according to theory hard and soft acids and bases (HSAB) [15]. In these conditions, it could enable to coordinate $\mathrm{Ag}$ species via the anion exchange mechanism. Therefore, the effect of the initial $\mathrm{pH}$ on the extraction of $\operatorname{Ag}(\mathrm{I})$ was examined. As shown in Fig. 1, the extraction of $\operatorname{Ag}(\mathrm{I})$, regardless of the extractant used, highly depends on the acidity of the aqueous phase. The extraction efficiency at $\mathrm{pH} \sim 1.0$ yielded values of 76,80 and $87 \%$ for TOA, DMEA, and BEHA, respectively. A decrease in the solution acidity resulted in a reduction of the extraction efficiency for all studied extractants, reaching the level below $30 \%$ at $\mathrm{pH}$ values above 6 . This pointed a high effectivity of examined amine (TOA). Furthermore, the separation of phases was very fast $(<15$ s), and no emulsion formation was noticed. 


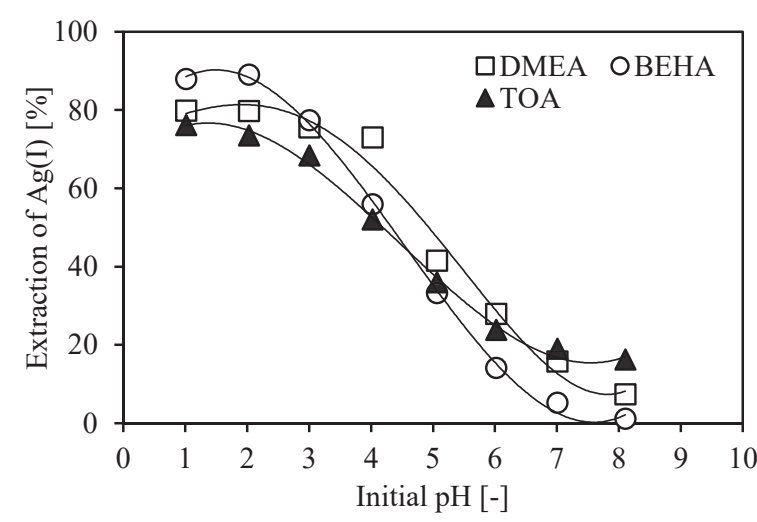

Fig. 1. Influence of initial $\mathrm{pH}$ on silver(I) extraction using BEHA, DMEA and TOA as extractants from chloride solution $([$ extractant $]=10 \%(\mathrm{v} / \mathrm{v}),[$ time $]=60 \mathrm{~s})$.

\subsection{Effect of contact time on silver(I) extraction}

The effect of contact time on silver uptake is presented in Fig. 2, where the extraction efficiency of silver(I) was plotted vs. time. The process was carried out at ambient temperature and the contact time was varied in the range of 5-120 minutes. The concentration of the extractants (BEHA, DMEA, TOA) was equal to $10 \%(\mathrm{v} / \mathrm{v})$. Phase ratio $\mathrm{A} / \mathrm{O}$ (aqueous/organic) equal to 1 . For two extractants (BEHA, DMEA), results show that the silver(I) ions were removed after $60 \mathrm{~min}$ of the shaking (Fig. 2). The extraction efficiency equals 89 and $82 \%$ for BEHA and DMEA, respectively. Results for TOA show that the majority of $\mathrm{Ag}(\mathrm{I})$ ions $(77 \%)$ was removed after a 30 min of shaking. A further increase of the extraction time up to $60 \mathrm{~min}$ was found to slightly increase the extraction efficiency. Therefore, contact time of $60 \mathrm{~min}$ was recommended as the time, which enables to achieve of an equilibrium of the silver extraction for all extractants. emulsion formation was noticed.

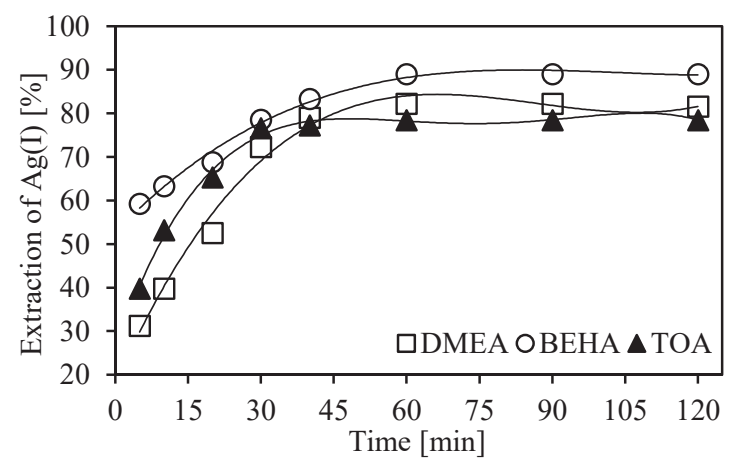

Fig. 2. Effect of contact time on silver(I) extraction using BEHA, DMEA and TOA as extractants from chloride solution $([$ extractant $]=10 \%(\mathrm{v} / \mathrm{v}),[$ time $]=5-120 \mathrm{~min}$.$) .$

\subsection{Effect of extractant concentration}

To study the effect of extractant concentration the content of BEHA, DMEA and TOA in organic phase was varied in the range of $2.5-20 \%(\mathrm{v} / \mathrm{v})$ (Table 3 and Fig. 3). Aqueous (A) and organic phases (O) were contacted for
60 minutes at phase ratio $\mathrm{A} / \mathrm{O}$ equal to 1 . Extraction was performed at ambient temperature. It was observed that extraction efficiency increases with increase in extractant concentration. The maximum extraction efficiency of silver(I) (89.3, 87.6 and $75.5 \%$, respectively) was obtained at the highest concentration of extractant (BEHA, DMEA and TOA, respectively), 20\% (v/v). Additionally, Table 3 presents the effect of extractant concentration on the distribution coefficient $(\mathrm{O} / \mathrm{A})$ on the studied extractants. It appears that extraction of $\mathrm{Ag}$ for all extractants increases with increasing extractant concentration, same as the extraction efficiency. This result can be explained considering increasing of number of extractant molecules which leads to increasing the uptake. Applying too high concentrations of extractant in organic phase while silver concentrations in solutions are low may be unprofitable. Therefore, it was assumed that optimal extractant concentration in described experiments would be $10 \%(\mathrm{v} / \mathrm{v})$.

Table 3. Silver(I) extraction using amine extractants (BEHA, DMEA and TOA) from chloride solutions.

\begin{tabular}{|c|c|c|c|c|c|c|}
\hline \multirow{2}{*}{$\begin{array}{c}\text { Extractant } \\
\text { concentration } \\
{[\%(v / v)]}\end{array}$} & \multicolumn{2}{|c|}{ DMEA } & \multicolumn{2}{|c|}{ ВEHA } & \multicolumn{2}{|c|}{ TOA } \\
\hline & $\begin{array}{c}E \\
{[\%]}\end{array}$ & D & $\begin{array}{c}\mathbf{E} \\
{[\%]}\end{array}$ & D & $\begin{array}{c}\mathbf{E} \\
{[\%]}\end{array}$ & D \\
\hline 2.5 & 7.5 & 0.1 & 4.3 & 0.05 & 3.6 & 0.04 \\
\hline 5 & 21.1 & 0.3 & 54.2 & 1.2 & 10.1 & 0.1 \\
\hline 7.5 & 68.1 & 2.1 & 82.2 & 4.6 & 45.1 & 0.8 \\
\hline 10 & 80.5 & 4.1 & 87.2 & 6,8 & 75.4 & 3.1 \\
\hline 15 & 85.5 & 5.9 & 87.9 & 7.2 & 75.4 & 3.1 \\
\hline 20 & 87.6 & 7.1 & 89.3 & 8.3 & 75.5 & 3.1 \\
\hline
\end{tabular}

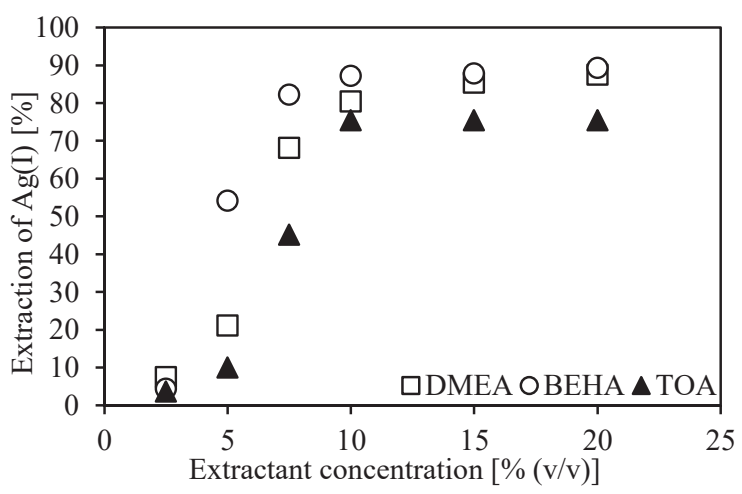

Fig. 3. Effect of extractant concentration on silver(I) extraction using BEHA, DMEA and TOA as extractants from chloride solution $([$ extractant $]=2.5-20 \%(\mathrm{v} / \mathrm{v}),[$ time $]=60 \mathrm{~min})$.

\subsection{Reextraction}

Stripping test was performed using freshly loaded and pre-filtered organic phases containing $77.4-89.3 \mathrm{mg} / \mathrm{L}$ of $\mathrm{Ag}(\mathrm{I})$ ions and $1.0 \mathrm{M}$ of stripping agents $\left(\mathrm{NH}_{3} \cdot \mathrm{H}_{2} \mathrm{O}\right.$, $\mathrm{NaOH}, \mathrm{NH}_{4} \mathrm{NO}_{3}$, and $\mathrm{NaNO}_{3}$ ) in the aqueous phase. Stripping of loaded organic was carried out at one to one volume ratios of loaded organic and stripping solutions. After the $60 \mathrm{~min}$ contact, the phases were allowed to disengage. The aqueous phases were separated and 
analysed. The results presented in Fig. 4 show that for all tested extractants were obtained low reextraction efficiency of $\mathrm{Ag}(\mathrm{I})$ using as a stripping agents: $\mathrm{NH}_{3} \cdot \mathrm{H}_{2} \mathrm{O}$, $\mathrm{NH}_{4} \mathrm{NO}_{3}$, and $\mathrm{NaNO}_{3}$. Yield of the reextraction process was not exceeded $23 \%$. The best stripping of $\operatorname{Ag}(\mathrm{I})$ ions from loaded organic phase in the case of all extractants (DMEA, BEHA, and TOA) was observed by using of 1.0 $\mathrm{M} \mathrm{NaOH}$ solution and reextraction efficiency was consecutively 54,57 and $77 \%$, respectively.

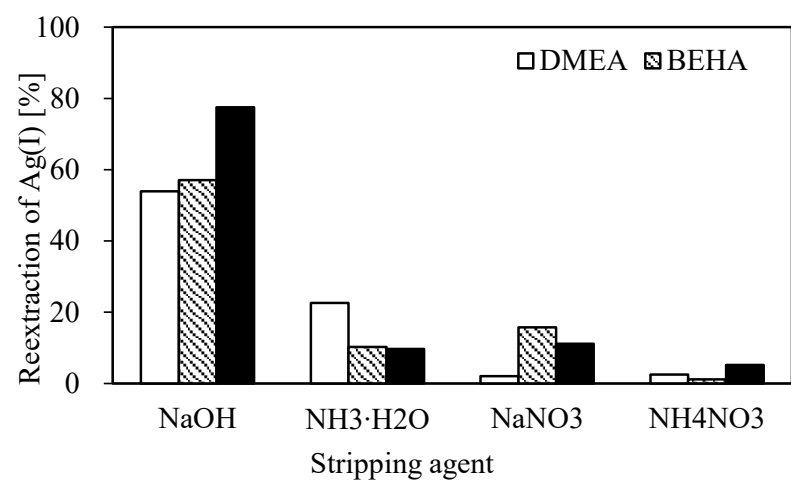

Fig. 4. Reextraction of silver(I) for amine extractants: BEHA, DMEA, and TOA $([$ extractant $]=10 \%(\mathrm{v} / \mathrm{v}),[$ time $]=60 \mathrm{~min})$.

Subsequently, the three stripping agents: $\mathrm{NH} 3 \cdot \mathrm{H} 2 \mathrm{O}$, $\mathrm{NH} 4 \mathrm{NO} 3$, and $\mathrm{NaNO} 3$, were discarded and the effect of sodium hydroxide concentration on silver(I) reextraction was investigated (Table 4). Studies were conducted under the same conditions for the range of $\mathrm{NaOH}$ concentration from 0.25 to $2.0 \mathrm{M}$. In case of the organic phase containing the loaded trioctylamine (TOA), the stripping of $\mathrm{Ag}(\mathrm{I})$ from the organic phase was most efficient. The use of $1.0 \mathrm{M} \mathrm{NaOH}$ as stripping agent resulted in a $77.5 \%$ recovery of $\mathrm{Ag}(\mathrm{I})$ in one-stage process, while using a 2.0 $\mathrm{M} \mathrm{NaOH}$ solution, the stripping of $\mathrm{Ag}(\mathrm{I})$ was until 78.7\%. Additionally, was used a concentration of $\mathrm{NaOH}$ equal to 1 it is sufficient, and further increasing the concentration was not appreciably increase the recovery of silver. The maximum extraction efficiency of silver(I) (64.6 and 67.1 $\%$ ) was obtained at the highest concentration of $\mathrm{NaOH}$ solutions for DMEA and BEHA (2M). For these extractants (DMEA and BEHA), the efficiency of the process varies considerably with the increase in concentration of $\mathrm{NaOH}$ solution.

Table 4. Effect of $\mathrm{NaOH}$ solution concentration on silver(I) reextraction using BEHA, DMEA and TOA as extractants.

\begin{tabular}{|c|c|c|c|}
\hline \multirow{2}{*}{$\begin{array}{c}\text { Concentration } \\
\text { of NaOH [M] }\end{array}$} & \multicolumn{3}{|c|}{ Reextraction [\%] } \\
\cline { 2 - 4 } & DMEA & BEHA & TOA \\
\hline 0.25 & 16.1 & 28.0 & 36.8 \\
\hline 0.50 & 44.1 & 54.9 & 71.0 \\
\hline 1.0 & 53.6 & 57.1 & 77.5 \\
\hline 1.5 & 56.3 & 59.6 & 77.9 \\
\hline 2.0 & 64.6 & 67.1 & 78.7 \\
\hline
\end{tabular}

\subsection{Extraction of silver(I) from multicomponent solutions after chloride leaching}

Silver(I) ions were also extracted from two chloride leaching solutions containing lead, copper, cobalt, nickel and zinc (composition in Table 2). Metals extraction were determined with an organic solution consisting of $10 \%$ each extractants (BEHA, DMEA, TOA) and aqueous phase at an $\mathrm{A} / \mathrm{O}$ ratio of $1: 1$ and ambient temperature. During extraction, no third phase formation was observed. Extraction efficiency of particular metals and separation factors for silver(I) were showed in Table 5 (a,b). It can be seen that the metal extraction order was $\mathrm{Ag}>\mathrm{Ni}>\mathrm{Pb}>\mathrm{Fe}>\mathrm{Zn}>\mathrm{Cu}>\mathrm{Co}$ for DMEA, $\mathrm{Ag}>>\mathrm{Fe}>\mathrm{Cu}>\mathrm{Zn}>\mathrm{Pb}>\mathrm{Ni}>\mathrm{Co}$ for BEHA and $\mathrm{Ag}>>\mathrm{Cu}>\mathrm{Zn}>\mathrm{Fe}>\mathrm{Co}>\mathrm{Pb}>\mathrm{Ni}$ for TOA (for solutions after chloride leaching: $\mathrm{a}$ - without $\mathrm{Fe}, \mathrm{b}$ - with $\mathrm{Fe}$ ). The highest co-extraction of metals was observed for extractants DMEA and TOA, where separation factors (S) were significantly lower than for BEHA. The maximum extraction efficiency of silver(I) was obtained for BEHA and extraction efficiency was equal to $85.2 \%$ (a) and $86.6 \%$ (b). Additionaly, in relation to other metals the most selectivity extractant for silver(I) was also extratant BEHA and co-extraction of metals was not exceed $8.0 \%$ in case of iron-free solution. In the case of second solution (b) was show considerable co-extraction of iron(III) from solution $(22.1 \%)$, which is confirmed by a lower partition coefficient in comparison to the others metals.

Table 5. Silver(I) extraction using amine extractants (BEHA, DMEA, TOA) from multicomponent solutions after atmosphere chloride leaching ( $\boldsymbol{a}$ - containing metal such as $\mathrm{Ag}(\mathrm{I}), \mathrm{Pb}(\mathrm{II}), \mathrm{Cu}(\mathrm{II}), \mathrm{Zn}(\mathrm{II}), \mathrm{Ni}(\mathrm{II}), \mathrm{Co}(\mathrm{II}), \boldsymbol{b}$ - containing metal such as $\mathrm{Ag}(\mathrm{I}), \mathrm{Pb}(\mathrm{II}), \mathrm{Cu}(\mathrm{II}), \mathrm{Zn}(\mathrm{II}), \mathrm{Ni}(\mathrm{II}), \mathrm{Co}(\mathrm{II}), \mathrm{Fe}(\mathrm{III})$.

\begin{tabular}{|c|c|c|c|c|c|c|c|}
\hline \multirow[b]{3}{*}{ Metal } & \multirow{3}{*}{$\begin{array}{c}C_{\text {intial }} \\
{[\mathrm{mg} / \mathrm{L}} \\
]\end{array}$} & \multirow{2}{*}{\multicolumn{2}{|c|}{ DMEA }} & \multirow{2}{*}{\multicolumn{2}{|c|}{ ВEHA }} & \multirow{2}{*}{\multicolumn{2}{|c|}{ TOA }} \\
\hline & & & & & & & \\
\hline & & $\begin{array}{c}\mathbf{E} \\
{[\%]}\end{array}$ & $\underset{\mathbf{A g} / \mathbf{M e}}{\mathbf{S}}$ & $\begin{array}{c}\mathbf{E} \\
{[\%]}\end{array}$ & $\underset{\mathrm{Ag} / \mathrm{Me}}{\mathrm{S}}$ & E [\%] & $\underset{\mathrm{Ag} / \mathrm{Me}}{\mathrm{S}}$ \\
\hline $\operatorname{Ag}(\mathrm{I})$ & 69.0 & 58.3 & - & 85.2 & - & 70.7 & - \\
\hline $\mathrm{Pb}(\mathrm{II})$ & 501.2 & 32.8 & 2.9 & 4.1 & 134.2 & 30.0 & 5.6 \\
\hline $\mathrm{Cu}(\mathrm{II})$ & 4507 & 17.1 & 6.8 & 7.8 & 67.9 & 66.5 & 1.2 \\
\hline $\mathrm{Zn}(\mathrm{II})$ & 175.4 & 19.6 & 5.7 & 7.1 & 75.6 & 42.0 & 3.3 \\
\hline $\mathrm{Ni}(\mathrm{II})$ & 14.9 & 45.6 & 1.7 & 0.9 & 610.2 & 14.0 & 14.8 \\
\hline $\mathrm{Co}(\mathrm{II})$ & 17.9 & 1.9 & 72.2 & 0.5 & 8.3 & 40.9 & 3.5 \\
\hline
\end{tabular}

\begin{tabular}{|c|c|c|c|c|c|c|c|}
\hline \multirow{2}{*}{ Metal } & \multirow{2}{*}{$\begin{array}{c}\text { Cintial } \\
{[\mathbf{m g} / \mathbf{L}} \\
\end{array}$} & \multicolumn{2}{|c|}{ DMEA } & \multicolumn{2}{c|}{ BEHA } & \multicolumn{2}{c|}{ TOA } \\
\cline { 3 - 8 } & $\begin{array}{c}\mathbf{E} \\
{[\%]}\end{array}$ & $\begin{array}{c}\text { S } \\
\text { Ag/Me }\end{array}$ & $\begin{array}{c}\mathbf{E} \\
{[\%]}\end{array}$ & $\begin{array}{c}\text { S } \\
\text { Ag/Me }\end{array}$ & $\begin{array}{c}\mathbf{E} \\
{[\%]}\end{array}$ & $\begin{array}{c}\text { S } \\
\text { Ag/Me }\end{array}$ \\
\hline $\mathrm{Ag}(\mathrm{I})$ & 46.2 & 58.4 & - & 86.6 & - & 74.0 & - \\
\hline $\mathrm{Pb}(\mathrm{II})$ & 501.2 & 19.6 & 5.8 & 1.4 & 462.5 & 10.0 & 25.5 \\
\hline $\mathrm{Cu}(\mathrm{II})$ & 364.2 & 3.3 & 41.4 & 9.3 & 62.8 & 45.3 & 3.4 \\
\hline $\mathrm{Zn}(\mathrm{II})$ & 12.4 & 14.5 & 8.3 & 3.1 & 198.9 & 30.5 & 6.5 \\
\hline $\mathrm{Ni}(\mathrm{II})$ & 15.3 & 49.7 & 1.4 & 0.2 & 3190 & 3.3 & 84.3 \\
\hline $\mathrm{Co}(\mathrm{II})$ & 23.7 & 0.7 & 213.3 & 0.1 & 6975 & 21.6 & 10.3 \\
\hline $\mathrm{Fe}(\mathrm{III})$ & 501.2 & 18.9 & 27.7 & 22.1 & 22.7 & 30.0 & 6.6 \\
\hline
\end{tabular}




\section{Conclusions}

BEHA, DMEA and TOA were used for the solvent extraction of silver(I) ions from synthetic chloride solutions, and tested from chloride pregnant leach solutions (PLS), coming from a atmosphere leaching of the copper flotation concentrate from Lubin Concentrator (KGHM Polska Miedź S.A.) The experimental results show that $\mathrm{Ag}(\mathrm{I})$ can be efficient extracted from solutions using amine extractant. The best results were obtained using bis(2-ethylhexyl)amine as extractant using xylene as diluent. Additionally, extraction of silver(I) was efficient until the 60 minutes contact time, process significantly depends on inital $\mathrm{pH}$ for all extractants (BEHA, DMEA and TOA) in the aqueous phase. The most effective results were obtained for initial $\mathrm{pH} \sim 1.0$ in the aqueous phase. Extraction process from chloride leaching solution was showed a large $\operatorname{Ag}(\mathrm{I})$ ions recovery for all using extractants, and also co-extraction of other ions (Cu(II), Pb(II), Zn(II), Ni(II), Co(II), Fe(III)) in small degree. The most selective extractant from chloride leaching solutions proved to be ekstractant BEHA, a high silver recovery rate of over $85 \%$. The stripping of $\operatorname{Ag}(\mathrm{I})$ ions from loaded organic phase in the case of BEHA, DMEA and TOA was the most efficient using $\mathrm{NaOH}$. The maximum extraction efficiency of silver(I) (64.6 and 67.1 and $78.7 \%$ ) was obtained at the highest concentration of $\mathrm{NaOH}$ solutions equal to $2 \mathrm{M}$ for extractants DMEA, BEHA and TOA.

\section{References}

1. A. Piestrzynski, Monography of KGHM Polska Miedź S.A., A. Piestrzynski (Ed.), (CPBM Cuprum Sp. z o.o. Publisher, Lubin, 201-237, in Polish, 2007)

2. T. Chmielewski, Sep. Sci. Technol. Separation Science and Technology 47(9) 1264-1277 (2012)

3. S. Syed, Waste Management 50, 234-256 (2016)

4. N. Sathaiyan, P. Adaikkalam, J.A.M.A. Kader, S. Visvanathan, Encyclopedia of Materials: Science and Technology (Second Edition, 8621-8623, 2001)

5. A.G. Chmielewski, T.S. Urbanski, W. Migdal, Hydrometallurgy 45(3) 333-344 (1997)

6. M.F. Almeida, M.A. Amarante, Miner. Eng. 8, $257-$ 271 (1995)

7. R. Briones, G.T. Lapidus, Hydrometallurgy 50, 243260 (1998)

8. A.M. Shafiqul, K. Inoue, K. Yoshizuka, Y. Dong, P. Zhang, Hydrometallurgy 44, 245-254 (1997)

9. Y. Abe, D.S. Flett,, Proc. Metall. 7, 1127-1132 (1992)

10. A. Cieszynska, M. Wisniewski, Sep. Purif. Technol. 80, 385-389 (2011)

11. A.P. Paiva, Sep. Sci. Technol. 28(4) 947 (1993)

12. A.P. Paiva, Solv. Extr. Ion Exch. 18(2) 223-271, (2000)

13 A.P. Paiva, Solvent Extr. 21st Century, Proc. ISEC '99, Society of Chemical Industry, 399-404, (2001)

14. K. Wejman-Gibas, M. Pilśniak-Rabiega, E3S Web of Conferences $\quad 8, \quad 01016, \quad$ DOI: 10.1051/e3sconf/20160801016. (2016)

15. R.G. Pearson, J. Am. Chem. Soc. 85, 3533 (1963) 